even over our airfields during testing of the equipment before operational flights. Moreover, many of their night-fighters were equipped with Naxos receivers, which as well as indicating the general whereabouts of the bomber stream could, in the hands of skilled operators, enable fighters to home on to individual bombers. Lovell is inclined to discount the success of Naxos; but if it was not successful, why did the Germans build as many as 1,500 Naxos receivers and progressively fit 700 of them into nightfighters?

Whatever the qualifications about the success of $\mathrm{H}_{2} \mathrm{~S}$ in Bomber Command, its success at sea was unqualified and had been gained by the devoted efforts of the team led by Lovell, and of others who worked closely with it. Nor was it work and inspiration alone that had been demanded of them: two of Lovell's team and three EMI workers, one of them A. D. Blumlein, were killed when their trials aircraft crashed in June 1942.

In Echoes of War, Lovell has provided an authoritative chronicle of the history of one of the greatest devices to emerge in the Second World War, and sheds internal light on the scientific and military cultures that developed in a free society determined to resist the Nazi threat. The fact that $\mathrm{H}_{2} \mathrm{~S}$ was in operational use only 15 months after its conception testifies to what inspired determination can do. And the fact that those 15 months included not only the fatal crash but also the upheaval of transferring the team and families from Swanage to Malvern in the spartan conditions of war adds to the marvel of the achievement.

R. V. Jones, from 1939 to 1945 head of scientific intelligence on Britain's Air Staff and scientific adviser to the British Secret Intelligence Service (M16), is at 8 Queen's Terrace, Aberdeen AB1 $1 X L$, UK.

- Nanotechnology will drastically alter the way in which we think about our lives, argue the authors of two recently published books. In Unbounding The Future (Morrow, \$23), K. E. Drexler, C. Paterson and G. Pergamit give a popular account of nanotechnology and what they believe might be its revolutionary consequences. More measured is The Vital Machine (Oxford University Press, £17.50), in which D. F. Channell takes a historical look at how various forms of technology have shaped the distinction we make between natural and artificial, alive and mechanical. - Cambridge University Press have reissued three introductions to particle physics. New in paperback is The Experimental Foundations of Particle Physics by R. N. Cahn and G. Goldhaber ( $£ 15.95, \$ 27.95$ ). New editions are The Ideas of Particle Physics by G. D. Coughlan and J. E. Dodd (2nd edn; £35. $\$ 59.95$ (hbk); £13.95, \$27.95 (pbk)) and Elementary Particles by I. S. Hughes (3rd edn; £50, \$80 (hbk); £16.95, \$29.95 (pbk)).

\section{Life and hard science}

\section{Walter Gratzer}

Five Billion Vodka Bottles to the Moon: Tales of a Soviet Scientist. By losif Shklovsky. Translated by Mary and Harold Zirin. Norton: 1991. Pp. 268. \$19.95, $£ 14.95$

THE story goes that when Khrushchev turned on Stalin, by then safely dead, one of his diatribes was checked by a voice from the hall, demanding to know why, if all he said was true, he had not spoken up when it mattered. Khrushchev flushed dangerously and slowly scanned the audience with his bloodshot eyes. Would the questioner identify himself? There was a chilling silence and then Khrushchev spoke again: "Now you know". Among the scientific community it was pre-eminently Kapitsa who stood up to Beria and Stalin. But there were other brave men who made no deals with the system and retained their selfrespect, among them the astrophysicist Iosif Shklovsky.

Shklovsky, it must be said, does not emerge from his discursive memoirs as an altogether attractive personality. "The style and flavour of Richard Feynman", promised by the blurb, is far removed from the querulous tone and leaden sarcasm here on display. But then while Feynman pursued his serene course to an early apotheosis, Shklovsky was being denied at every turn, thwarted in his own country of the recognition that he craved, harassed by the endemic antisemitism of the Soviet establishment and oppressed by a brainless and pusillanimous bureaucracy. He fought the system with tireless tenacity until the casual incompetence of the doctors at the Soviet Academy of Sciences hospital put an end to him. It was Dumas fils who said that rogues are preferable to imbeciles because they sometimes take a rest.

Despite the rancorous descant, Shklovsky's story is a valuable and often absorbing record of the time. Science hard enough, God knows, even when everything is in your favour and everyone is on your side - ought to have been all but impossible in the conditions with which Shklovsky had to contend. He chronicles, for instance, the fall of the celebrated astronomer. Numerov, who was denounced to the Communist Party by an unsuccessful graduate student out for revenge. Numerov under torture signed a fabricated confession, admitting his part in an anti-Soviet conspiracy and implicating two dozen of his colleagues. The contagion spread and in the end some 80 of the best astronomers in the country were imprisoned and most of them lost their lives.

The absurdities to which fear and bureaucratic paralysis could lead are illustrated in many chilling anecdotes, often rich in black humour. In the Karpov Physical Chemistry Institute, an order was posted containing, over the signature of the director, the following article: "4. Associate of the Electrochemical Laboratory Comrade Morokhov is hereby reprimanded for applying to the Karpov Institute a word that in the language of poorly educated people is used to denote a house of prostitution." A month later another order appeared, rescinding article 4, and thus, as Shklovsky notes, endorsing Comrade Morokhov's thesis. And here is an example of Soviet medicine at work: Shklovsky, in the academy hospital after his first heart attack, takes his pulse to save the doctor the trouble. "Seventy-three", he announces. The doctor, a welldressed young woman, and therefore surmisedly the daughter of an academy panjandrum, replies that this is impossible, the heartbeat is always an even number: her method, it turns out, is to count for half a minute and then double the result.

Shklovsky comes across then as crossgrained, unyielding and valiant, a pain to the apparat and often probably to his friends, not given to self-doubt and sustained by his high opinion of his abilities and accomplishments, which he is not bashful about enumerating. And who should say his pride misplaced? His story is marvellously translated and edited by Mary and Harold Zirin, the latter himself a professor of astronomy at Caltech and director of its observatory. It is their insiders' knowledge of the man, his science and the social and professional milieu in which he functioned that make this book rewarding. Here is Shklovsky, weak with hunger on a farm in the remote provinces, stealing potatoes; he becomes proficient at gathering them, he says, by the method of Mamlakat. The editorial footnote explains: "Mamlakat Nakhangova was a little Uzbek girl, who became a heroine of labour for picking cotton with both hands." Now where else could one have learned that?

Walter Gratzer is in the MRC Cell Biophysics Unit, King's College London, 26-29 Drury Lane, London WC2B 5RL, UK.

Leigh Royden's review of The Solid Earth (Nature 354, 30; 1991) inadvertently rendered the author of the book, Mary Fowler, male. The mistake was made in the editorial office of Nature. 